\title{
Minute Times Picogram per Milliliter
}

National Cancer Institute

\section{Source}

National Cancer Institute. Minute Times Picogram per Milliliter. NCI Thesaurus. Code C85734.

Minutes times picograms per milliliter. 